\title{
NEW SARCOPTERYGIANS FROM THE CARBONIFEROUS POTI FORMATION AND FROM THE PERMIAN RIO DO RASTO FORMATION, BRAZIL
}

\author{
RODRIGO TINOCO FIGUEROA, RAPHAEL MIGUEL \& VALÉRIA GALLO \\ Laboratório de Sistemática e Biogeografia, Departamento de Zoologia, Instituto de Biologia, UERJ, Rua São Francisco Xavier, \\ 524, Maracanã, 20550-013, Rio de Janeiro, RJ, Brazil.rotinof@gmail.com,rmsilva205@gmail.com,gallo@uerj.br
}

\begin{abstract}
A new material of sarcopterygian fishes from the Mississippian of the Poti Formation and the Lopingian of the Rio do Rasto Formation are described here. The specimens consist of isolated scales, which show numerous thin and parallel growth lines, a pattern of ornamentation usually found in actinistians, differing from the Westoll-lines present in dipnoans. A precise identification of this new material was not possible, because the scales lack more accurate diagnostic features. The Mississippian occurrence spreads the distribution of coelacanthiforms in the Brazilian Paleozoic, which was restricted to the Permian. This material represents the oldest actinistian record in Brazil and the first Mississippian report of this group from South America. The occurrences from the Rio do Rasto Formation seems to have freshwater affinities, which was inferred by the depositional environment and associated biota. All these new data are important to the comprehension of coelacanths paleogeographical distribution during the Paleozoic in South America.
\end{abstract}

Key words: coelacanths, scales, Poti Formation, Rio do Rasto Formation.

RESUMO - Novos espécimes de sarcopterígios do Mississipiano da Formação Poti e do Lopingiano da Formação Rio do Rasto são aqui descritos. Estes espécimes consistem em escamas isoladas, que exibem numerosas linhas de crescimento finas e paralelas, um padrão de ornamentação comum aos actinístias, o que as difere daquelas de dipnoicos que possuem linhas de Westoll. Uma identificação mais precisa do material não foi possível por causa da ausência de mais caracteres diagnósticos. A ocorrência mississipiana amplia a distribuição de celacantos no Paleozoico brasileiro, que estava restrita ao Permiano. Esse material representa o mais antigo celacanto brasileiro e a primeira ocorrência desse grupo na América do Sul. As ocorrências da Formação Rio do Rasto parecem ter afinidades dulciaquícolas, que foram inferidas em função do ambiente deposicional e biota associada. Todos estes novos dados são importantes para melhor compreender a distribuição dos celacantos durante o Paleozoico na América do Sul.

Palavras-chave: celacantos, escamas, Formação Poti, Formação Rio do Rasto.

\section{INTRODUCTION}

Description of isolated scales of sarcopterygians is usual in the literature, mainly related to coelacanths. The first coelacanth scale was described by Saint-Seine (1950), who erected the Jurassic genus Rhipis, with the type-species Rhipis moorseli. Casier (1965) named a new species for Rhipis, Rhipis tuberculata, and pointed out the occurrence of an undetermined species. Schaeffer (1962) erected the Devonian genus Chagrinia also based only on features of the scales. Forey (1981) pointed out that the dubious species of the Carboniferous genus Rhabdoderma could be distinguished by the pattern of ornamentation of scales. In the Upper Triassic of Canada, a scale of coelacanth was reported, which probably belongs to the genus Garnbergia, due to its ornamentation resembling that of the type-species Garnbergia ommata (Yabumoto \& Neuman, 2004). These authors also examined scales of the Triassic mawsoniid coelacanths Chinlea and Diplurus, and they verified that the scales differ by the presence of a major number of ridges in Chinlea, as well as by the presence of tubercles in Diplurus.

Although dipnoans are known mostly for their tooth plates, there are few descriptions of scales. For instance, Young \& Muddy (2002) furnished a comprehensive study of the fish fauna from Devonian of Venezuela, in which they described an unequivocal large ovoid lungfish scale.

Some taxa are easily distinguished by scale morphology and histology. However, the different types of rhomboid and elasmoid scales are distributed within Sarcopterygii and Actinopterygii (Schultze, 2016). The common ganoid scale of lower Actinopterygii is sometimes ornamented with grooves or ridges, however the growth lines are not visible at the scale surface due to the ganoine and enamel layers overlapping them (Sire et al., 2009; Schultze, 2016). Cosmoid scales (the other type of rhomboid scales besides ganoids) are typical of Sarcopterygii, however not all members of this clade, such as Actinistia, possess this type of scale (Meinke, 1984; Schultze, 2016). Actinistia exhibits typical elasmoid scales, 
with ornamentation in their exposed portion. A similar scale pattern is seen in tristichopterids into Osteolepiformes (see Young, 2008), but differ from the actinistian morphotype by more fragile ornamentation of ridges. In addition, the ornamented surface of tristichopterids covers almost half of the scale surface, contrasting with the smaller ornamented portion of Actinistia.

In South America, the records of Paleozoic sarcopterygians are mostly present in the Permian and they are represented mainly by isolated scales. They occur in the Permian of Bolivia (Vitiacua Formation; Janvier, 1991), Brazil (Pedra de Fogo, Corumbataí, Tatuí and Irati formations; Weiss \& Garcia, 2005; Chahud \& Petri, 2012; Miguel et al., 2015a) and Uruguay (Mangrullo Formation; Piñeiro et al., 2012), but they are poorly described (Miguel et al., 2015a,b). The exception is an angular bone attributed to Coelacanthus from Vitiacua Formation (Janvier, 1991) and a pterygoid from Pedra de Fogo Formation, which is similar to those found in Rhabdoderma (Weiss \& Garcia, 2005). In addition, there is a record of a dipnoan scale from Devonian of Venezuela (Young \& Muddy, 2002).

Invertebrates (e.g. bivalves and brachiopods) and vertebrates compose the paleofauna of the Poti Formation. The vertebrate fauna includes spine of Xenacanthus tocantinsensis, as well as paleoniscoid remains (Santos \& Salgado, 1970; Santos \& Carvalho, 2009). The Riacho Berlengas outcrop yielded a spine attributed to a ctenacanthid (Brito \& Ferreira, 1985). In addition, there are some fragments of bones and scales, which probably belong to paleoniscoids (Figueroa \& Machado, 2015). The paleofauna of the Rio do Rasto Formation is composed by conchostracans and mollusks (Ferreira-Oliveira \& Rohn, 2010; Simões et al., 2015) associated with a vertebrate fauna represented by chondrichthyans (e.g. sphenacanthids and xenacanthids; Pauliv et al., 2012, 2014), actinopterygians (e.g. Dias, 2012), dipnoan tooth plates (e.g. Toledo \& Bertini, 2005). Other vertebrates from the Rio do Rasto Formation include temnospondyl records (e.g. Ramos \& Vega, 2011; Eltink \& Langer, 2014), pareiasaurs, archosaurs and synapsids (e.g. Martinelli et al., 2016), besides of the ichnofossils reported by Dentzien-Dias et al. (2012) and Silva et al. (2012).

The goal of this study is to describe some coelacanth scales from the Poti Formation, lower Carboniferous (Mississippian) of the Parnaíba Basin, and from the Rio do Rasto Formation, upper Permian (Lopingian) of the Paraná Basin.

\section{MATERIAL \& METHODS}

The material from the Mississippian Poti Formation is represented by only one isolated incomplete scale. It was collected in 2009 by Deusana Maria da Costa Machado and is housed at the Paleontological Collection of the Laboratório de Estudos de Comunidades Paleozoicas at the Departamento de Ciências Naturais of the Universidade Federal do Estado do Rio de Janeiro, State of the Rio de Janeiro, Brazil, under the catalogue number UNIRIO 007-Px. This specimen was collected in the Riacho Berlengas outcrop, $11 \mathrm{~km}$ to the southeast from the Barro Duro County $\left(5^{\circ} 49^{\prime} 01,88^{\prime \prime} \mathrm{S}\right.$, $42^{\circ} 30^{\prime} 54,05^{\prime \prime} \mathrm{W}$ ), State of Piauí, Brazil (Figure 1).

The material from the Lopingian of the Rio do Rasto Formation includes three isolated incomplete scales. They were collected in 2002 by Fernando Sedor and Rafael Costa da Silva and are housed at the Paleontological Collection of the Museu de Ciências Naturais at the Universidade Federal do Paraná, Curitiba, State of Paraná, Brazil, under the catalogue numbers MCN.P.1197, 1198 and 1199. They

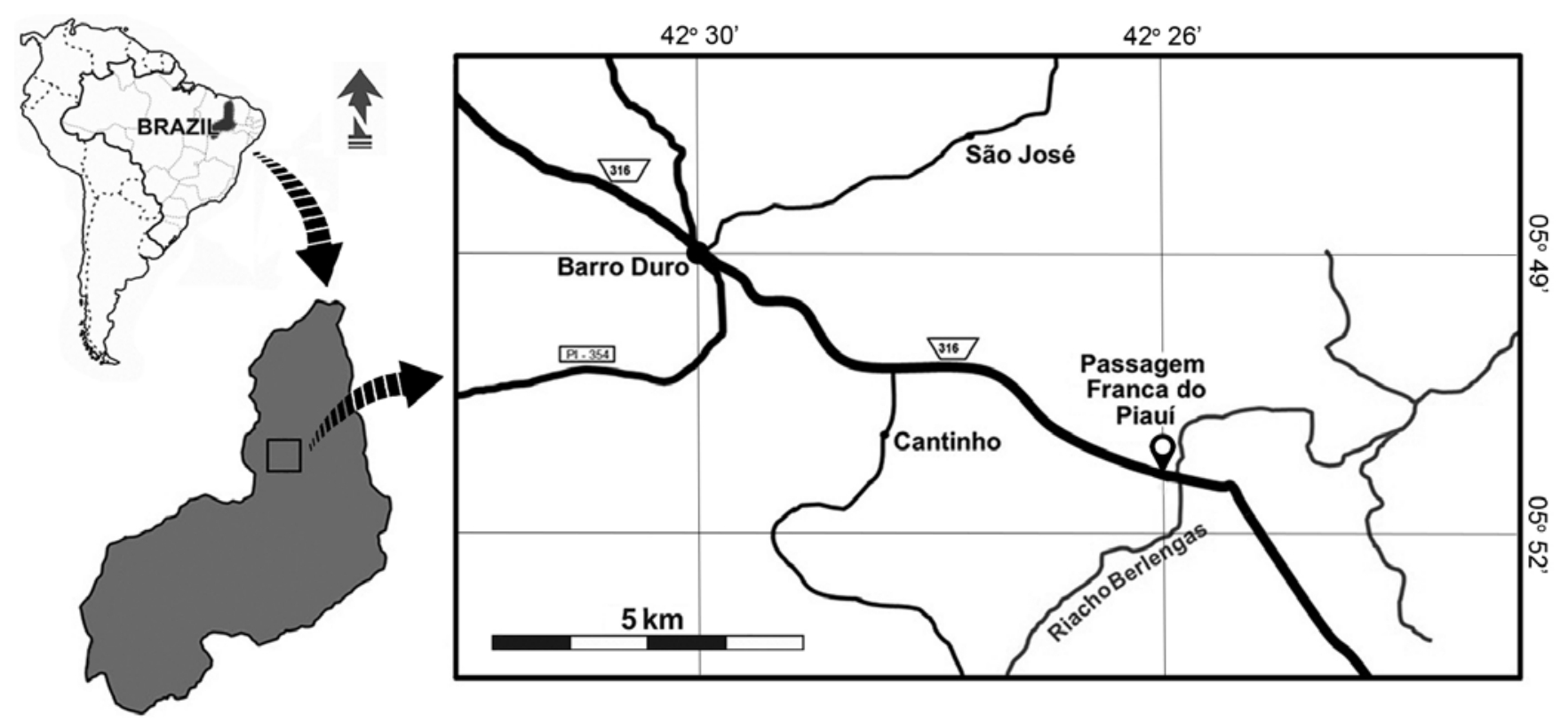

Figure 1. Location map of the collection locality in Mississippian Poti Formation, State of Piauí, Brazil. 
come from the locality of Serra do Espigão (26 44'55,92”'S, $\left.50^{\circ} 18^{\prime} 55,38^{\prime \prime} \mathrm{W}\right)$, State of Santa Catarina, Brazil (Figure 2).

Taking into account the absence of Westoll-lines in the studied scales, we compared the specimens reported here with the actinistian scales belonging to specimens of Changxingia and Youngichthys housed at the Institute of Vertebrate Paleontology and Paleoanthropology (China), and Diplurus, Rhabdoderma, and Chinlea housed at the American Museum of Natural History (United States) and Natural History Museum (United Kingdom), by directed observation, with Chagrinia, Rhipis, and Garnbergia using high resolution photographs, as well as from the available literature (e.g. Casier, 1965; Schaeffer, 1962; Yabumoto \& Neuman, 2004). Most of the specimens permit only inferences about the distal area, which is ornamented.

Description of actinistian scales is usually based on their morphology (see for instance, Forey, 1981; Yabumoto \& Newman, 2004; Chahud \& Petri, 2012). The number of ridges, further of their arrangement and morphology, is a useful tool to identify these scales.

Institutional abbreviations: MCN.P, Museu de Ciências Naturais, Peixes; UNIRIO Px, Universidade Federal do Estado do Rio de Janeiro, Peixes.

\section{SYSTEMATIC PALEONTOLOGY}

\section{Class SARCOPTERYGII Romer, 1955}

Subclass ACTINISTIA Cope, 1871

(Figures 3-6)

Material. The material from the Poti Formation (UNIRIO007-Px) is constituted by a fragmented scale of about $3 \mathrm{~mm}$ long and $5 \mathrm{~mm}$ wide. The material from the Rio do Rasto Formation is constituted by three scales, apparently showing different morphotypes (MCN.P.1197, 1198, 1199), with similar morphology and pattern of ornamentation usually found in actinistians.

Description. The poor preservation of the specimen UNIRIO-007-Px does not allow delimiting the true shape of the entire scale, but the pattern of ornamentation is clearly observable and typical of the coelacanths. The anterior portion of the scale exhibits a series of delicate growth lines, as imprints. The ornamentation on the exposed portion is represented by conspicuous ridges (Figure 3). MCN.P.1197 is preserved as an imprint and it is partially broken, therefore we are unable to describe the precise shape of the scale, but it seems to be rounded. The maximum length is about $26 \mathrm{~mm}$, the width is about $11 \mathrm{~mm}$ and the exposed field is about $4 \mathrm{~mm}$ long (Figure 4 ). The anterior portion of the scale bears numerous thin and parallel growth lines. The scale bears about 20 very close well-marked ridges intercalated with grooves on its posterior portion (exposed portion). The anterior margin of the exposed portion appears to be triangular. MCN.P.1198 is a fragmented scale apparently thick with $10 \mathrm{~mm}$ in estimated width. It seems to lack ornamentation, except in the posterior margin (pattern commonly found in Actinistia) (Figure 5), being represented by parallel and straight ridges. MCN.P.1198 differs from MCN.P.1197 in size, shape, and type of ornamentation. The MCN.P. 1199 is a $15 \mathrm{~mm}$ long and $3.5 \mathrm{~mm}$ wide fragment. It shows mineralized collagen fibers running from the focus to the borders of the scale (Figure 6). The growth lines are well spaced and slightly curved, not visible near the scale focus. The collagen fibers run parallel each other, but their angle changes in the boundary with growth line, forming a zigzag pattern. Such a zigzag pattern is known in the extant coelacanth Latimeria (Meunier et al., 2008) and an isolated Triassic actinistian scale (Romano et al.,
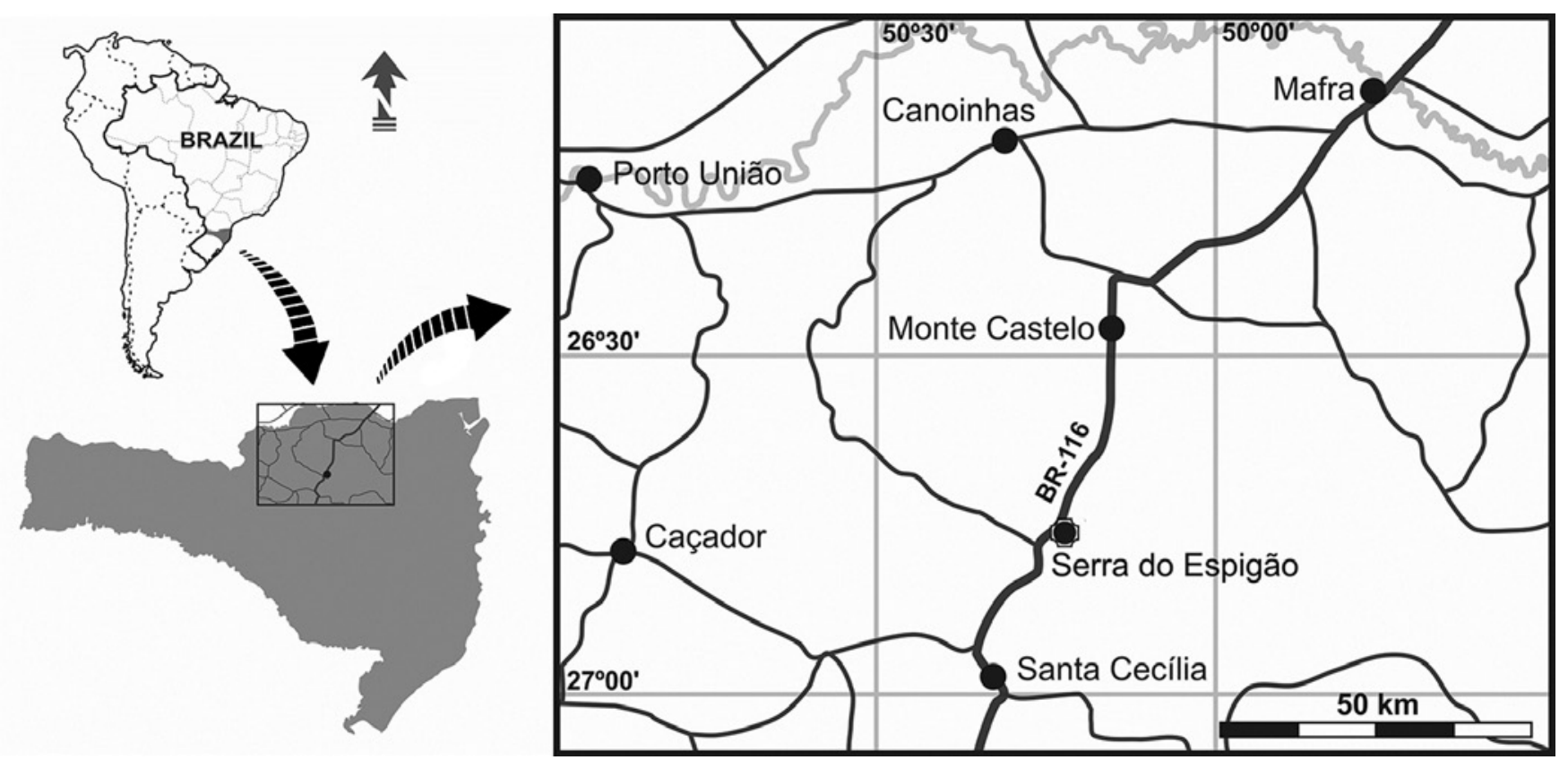

Figure 2. Location map of the of the collection locality in Lopingian Rio do Rasto Formation, State of Santa Catarina, Brazil. 


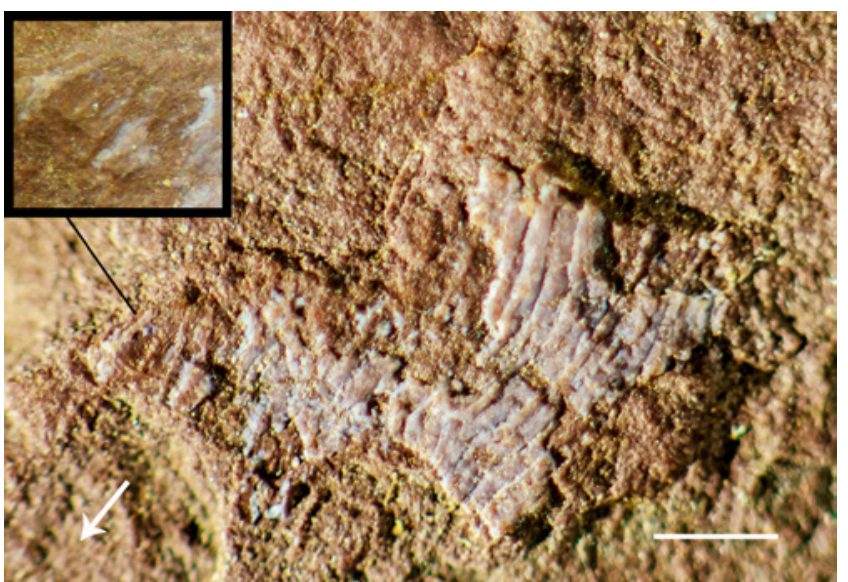

Figure 3. Incomplete scale from the Poti Formation (UNIRIO-007-Px) Above left, detail of the growth lines. Arrow indicates anterior direction. Scale bar $=1 \mathrm{~mm}$.

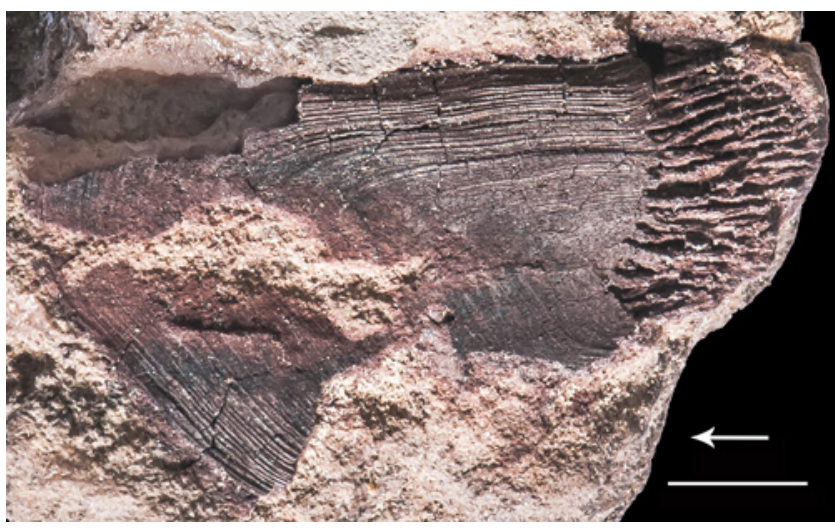

Figure 4. Subcomplete scale from the Rio do Rasto Formation (MCN.P.1197). Arrow indicates anterior direction. Scale bar $=5 \mathrm{~mm}$.

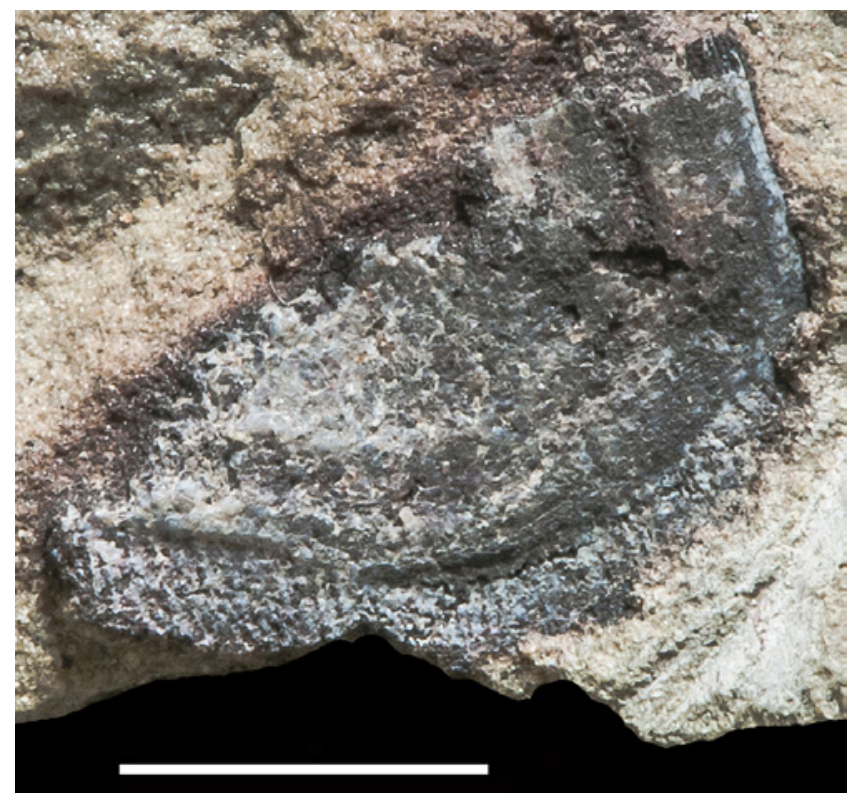

Figure 5. Incomplete scale from the Rio do Rasto Formation (MCN.P.1198). Scale bar $=5 \mathrm{~mm}$.
2012). These new materials from the Poti and Rio do Rasto formations were assigned to Actinistia, due to their typical pattern of ornamentation. A classification in a least inclusive taxonomical level was not possible, because they lack other diagnostic features.

\section{DISCUSSION}

The scales herein studied show numerous thin and parallel growth lines, a pattern of ornamentation usually found in actinistians, differing from the Westoll-lines present in dipnoans.

Actinistia (coelacanths) is a clade of sarcopterygian fishes (lobe-finned fishes) mainly represented in the fossil record. The group shows a remarkable distribution in the Paleozoic and Mesozoic, with numerous occurrences in Pangea (mainly in its Northern portion), and later in Gondwana and Laurasia (see Forey, 1998). The only living member of this group is represented by the genus Latimeria, found along the Eastern African Coast (from the Comoran Archipelago to South Africa) and in Indonesia (Island of Manado Tua, Sulawesi region) (Smith, 1939; Erdmann et al., 1998; Forey, 1998).

These are the first records of coelacanths from the Poti and Rio do Rasto formations. The coelacanths from the Permian of South America differ from Rhabdoderma in the ornamentation pattern of the scales (Forey, 1981). Furthermore, this genus does not occur in the Permian, which also indicates that the pterygoid from Pedra de Fogo (Alves, 2010) does not belong to this taxon.

The Mississippian Riacho Berlengas outcrop shows freshwater or even influence of coastal environment (Figueroa \& Machado, 2015). No coelacanth record in the Devonian or Carboniferous periods has been found in South America until now. Therefore, the Poti Formation coelacanth occurrence is important for understanding the biogeographic distribution of this group in the Paleozoic of South America.

According to Chahud \& Petri (2008), basins with coelacanth occurrences were interconnected during the Permian times by continental ways, probably through rivers and lakes. The presence of freshwater conchostracans confirms the lacustrine paleoenvironment in the Rio do Rasto Formation (Ferreira-Oliveira \& Rohn, 2010). The lower Permian of Pedra de Fogo and Irati formations shows a faunal similarity, especially by the occurrences of xenacanthids and the petalodont Itapyrodus punctatus (Chahud \& Petri, 2008) and now coelacanths. These faunal similarities also can be used to support connections among these units during the Permian.

The distribution of coelacanths during Lopingian is very scarce. In a comprehensive review of coelacanth fishes, Forey (1998) listed Coelacanthus, Changxingia and Youngichthys as the only late Permian taxa. The two last mentioned coelacanths were found in China and their scales are distinguishable by their respective shape (in Changxingia it is oval, in contrast with the elliptical scales of Youngichthys) (Wang \& Liu, 1981). 


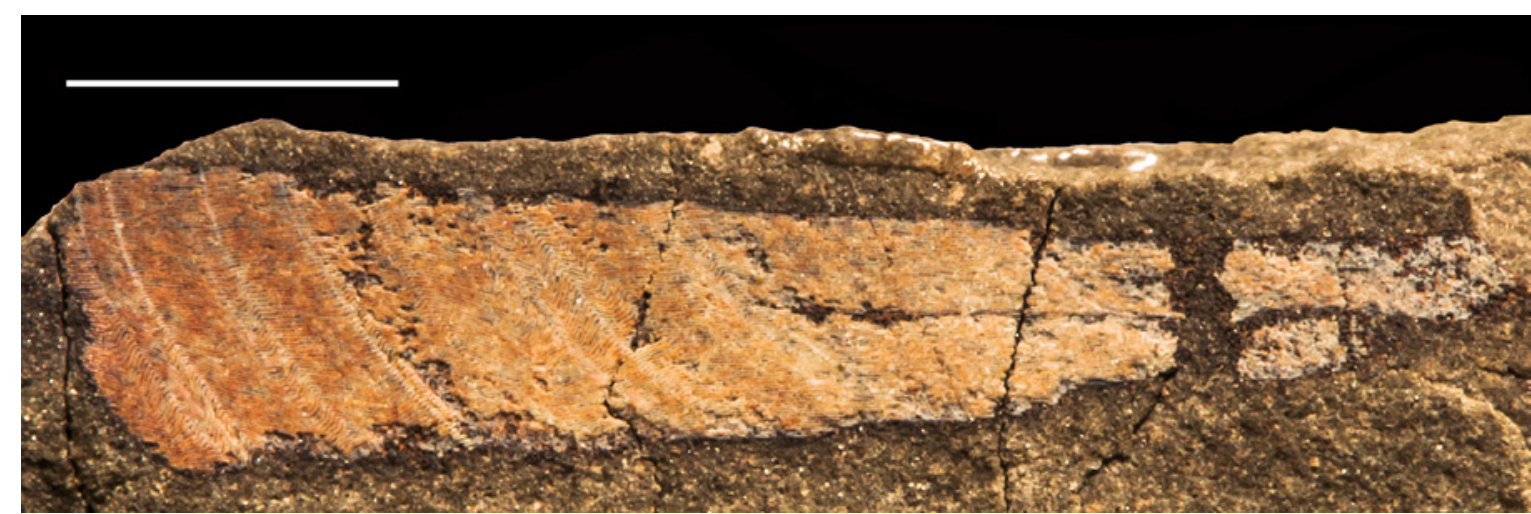

Figure 6. Incomplete scale from the Rio do Rasto Formation (MCN.P.1199). Scale bar $=5 \mathrm{~mm}$.

\section{CONCLUSIONS}

These incomplete scales described here exhibit similar ornamentation to Coelacanthiformes, which support its classification in this group. These new occurrences in South America emphasize the widespread distribution of coelacanths during the Paleozoic. The Mississippian occurrence extends the distribution of Actinistia in the Paleozoic of Brazil, which was so far restricted to the Permian. In addition, the material described herein is carefully considered the oldest actinistian record of Brazil and the first Mississippian occurrence for South America. These new data are important to understand the distribution of coelacanths during the Paleozoic of South America. The Lopingian occurrences from the Rio do Rasto Formation seems to have had freshwater affinities, inferred from the depositional environment and associated biota, which supports eventual connections between South American basins in the Permian.

\section{ACKNOWLEDGEMENTS}

We are most grateful to R.C. Silva (Companhia de Pesquisa de Recursos Minerais - CPRM) for kindly providing the illustration of the Rio do Rasto Formation collection locality and F. Sedor (Universidade Federal do Paraná - UFPR) for kindly provide the specimens from the Rio do Rasto Formation for study. Besides, R.C. Silva kindly provides the illustration of the Rio do Rasto Formation collection locality, and F. Sedor encouraging the development of this paper. We also thank D.M.C. Machado, from Universidade Federal do Estado do Rio de Janeiro, for providing the specimen from the Poti Formation for study. We are in debit to M. Ryan, from Case Western Reserve University (Cleveland), for kindly send the high-resolution photographs of the holotype of Chagrinia enodis. This research was supported by grants from Fundação Carlos Chagas de Amparo à Pesquisa do Estado do Rio de Janeiro (FAPERJ), Conselho Nacional de Desenvolvimento Científico e Tecnológico (CNPq), and UERJ. R.M. and R.F. held fellowships from the FAPERJ (Rio de Janeiro State Government). V.G. has research fellowship grants from $\mathrm{CNPq}$ (Brazilian Federal Government) and from the PROCIÊNCIA (Rio de Janeiro State Government).

\section{REFERENCES}

Alves, Y.M. 2010. Los vertebrados fósiles del Paleozoico y Mesozoico del estado de Tocantins (Brasil): Preliminar síntesis. Caminhos de Geografia, 11:224-236.

Brito, P.M. \& Ferreira, C.S. 1985. Contribuição ao estudo dos Cladoseláquios da Bacia do Maranhão-Piauí. In: CONGRESSO BRASILEIRO DE PALEONTOLOGIA, 9, 1985. Livro de resumos, Fortaleza, p. 130.

Casier, E. 1965. Poissons fossiles de la serie du Kwango (Congo). Annales du Musee Royal de L'Afrique Centrale, Tervuren, sciences Geologiques, 50:1-64.

Chahud A. \& Petri S. 2008. Chondrichthyes no Membro Taquaral, base da Formação Irati, no centro-leste do Estado de São Paulo, Brasil. Revista de Geologia, 21:169-179.

Chahud, A. \& Petri, P. 2012. Sarcopterygii do Eopermiano da Bacia do Paraná, Estado de São Paulo. Revista do Instituto Geológico, 33:57-64. doi:10.5935/0100-929X.20120011

Dentzien-Dias, P.C.; Figueiredo, A.E.Q.; Horn, B.; Cisneros, J.C. \& Schultze, C.L. 2012. Paleobiology of a unique vertebrate coprolite concentration from Rio do Rasto Formation (Middle/ Upper Permian), Paraná Basin, Brazil. Journal of South American Earth Sciences, 40:53-62. doi:10.1016/j.jsames.2012.09.008

Dias, E.V. 2012. Anew deep-bodied fossil fish (Actinopterygii) from the Rio do Rasto Formation, Paraná Basin, Brazil. Zootaxa, 3192:1-23.

Eltink, E. \& Langer, M.C. 2014. A new specimen of the temnospondyl Australerpeton cosgriffi from the late Permian of Brazil (Rio do Rasto Formation, Paraná Basin): comparative anatomy and phylogenetic relationships. Journal of Vertebrate Paleontology, 34:524-538. doi:10.1080/02724634.2013.826667

Erdmann, M.; Caldwell, R.L. \& Kasim Moosa, M. 1998. Indonesian "king of the sea" discovered. Nature, 395:335. doi: $10.1038 / 26376$

Ferreira-Oliveira, L.G. \& Rohn, R. 2010. Lealiid conchostracans from the uppermost Permian strata of the Paraná Basin, Brazil: Chronostratigraphic and paleobiogeographic implications. Journal of South American Earth Sciences, 29:371-380. doi:10.1016/j.jsames.2009.03.006

Figueroa, R.T. \& Machado, D.M.C. 2015. Paleoictiologia e tafonomia do Afloramento Riacho Berlengas, Formação Poti (Mississipiano da Bacia do Parnaíba). Paleontologia em Destaque, 68:129.

Forey, P.L. 1981. The coelacanth Rhabdoderma in the Carboniferous of the British Isles. Palaeontology, 24:203-229.

Forey, P.L. 1998. History of the Coelacanth Fishes. 1 ed. London, Chapman \& Hall, 419 p. 
Janvier, P. 1991. The Permian and Triassic vertebrates of Bolivia. In: SUAREZ-Soruco, R. (Ed.) Fosiles Y Facies de Bolivia, Vol I. - Vertebrados. Revista Técnica de YPFB, p. 3-4.

Martinelli, A.G.; Franscischini, H.; Dentzien-Dias, P.C.; Soares, M.B. \& Schultz, C.L. 2016. The oldest archosauromorth from South America: postcranial remains from the Guadalupian (MidPermian) Rio do Rasto Formation (Paraná Basin), southern Brazil. Historical Biology. doi:10.1080/08912963.2015.1125897

Meinke, D.K. 1984. A review of cosmine: its structure, development and relationship to other forms of the dermal skeleton in osteichthyans. Journal of Vertebrate Paleontology, 4:457-470. doi:10.1080/02724634.1984.10012022

Meunier, F.J.; Erdmann, M.V.; Fermon, Y. \& Caldwell, R.L. 2008. Can the comparative study of the morphology and histology of the scales of Latimeria menadoensis and L. chalumnae (Sarcopterygii: Actinistia, Coelacanthidae) bring new insight on the taxonomy and biogeography of recent coelacanthids? In: L. Cavin; A. Longbottom \& M. Richter (eds.) Fishes and the breakup of the Pangaea. London, Geological Society of London, p. 351-360 (Special Publications 295). doi:10.1144/SP295.17

Miguel, R.; Gallo, V. \& Brito, P.M. 2015. Parsimony Analysis of Endemicity of coelacanths in the Permian of South America. Paleontologia em Destaque, 68:136.

Miguel, R.; Gallo, V.; Sedor, F. \& Silva, R.C. 2015. The first record of coelacanths in the Rio do Rasto Formation, Upper Permian of the Paraná Basin, Southern Brazil. In: PALEO RJ/ES 2014, Boletim de Resumos, Paleontologia em Destaque, 68:135.

Pauliv, V. E.; Dias, E. V. \& Sedor, F. A. 2012. A new sphenacanthid (Chondrichthyes, Elasmobranchii) from the Rio do Rasto Formation (Paraná Basin), southern Brazil. Revista Brasileira de Paleontologia, 15:243-250. doi:10.4072/rbp.2012.3.01

Pauliv, V.E.; Dias, E.V.; Sedor, F.A. \& Ribeiro, A.M. 2014. A new Xenacanthiformes shark (Chondrichthyes, Elasmobranchii) from the Late Paleozoic Rio do Rasto Formation (Paraná Basin), Southern Brazil. Anais da Academia Brasileira de Ciências, 86:135-145. doi:10.1590/0001-37652014107612

Piñeiro, G.; Ramos, A.; Goso, C.; Scarabino, F. \& Laurin, M. 2012. Unusual environmental conditions preserve a Permian mesosaur-bearing Konservat-Lagerstätte from Uruguay. Acta Palaeontologica Polonica, 57:299-318. doi:10.4202/app.2010.0113

Ramos, B.D. \& Vega, C.S. 2011. Temnospondyl remains from the Late Permian Rio do Rasto Formation (Paraná Basin) of Brazil. Revista Brasileira de Paleontologia, 14:67-74. doi:10.4072/rbp.2011.1.07

Romano, C; Kogan, I; Jenks, J; Jerjen, I. \& Brinkmann, W. 2012. Saurichthys and other fossil fishes from the late Smithian (Early Triassic) of Bear Lake County (Idaho, USA), with a discussion of saurichthyd palaeogeography and evolution. Bulletin of Geosciences, 87:543-570. doi:10.3140/bull.geosci.1337.

Santos, M.E.C. \& Carvalho, M.S.S. 2009. Paleontologia das Bacias do Parnaíba, Grajaú e São Luis. Rio de Janeiro. Serviço Geológico do Brasil CPRM, 215 p.

Santos, R.S. \& Salgado, M.S. 1970. Um espinho de Xenacanthus do Carbonífero do Estado do Maranhão. Anais da Academia Brasileira de Ciencias, 42:223-227.

Schaeffer, B. 1962. A coelacanth fish from the Upper Devonian of Ohio. Scientific Publications of the Cleveland Museum of Natural History, 1:1-13.

Schultze, H.-P. 2016. Scales, enamel, cosmine, ganoine, and early osteichthyans. Comptes Rendus Palevol, 15:83-102. doi: 10.1016/j.crpv.2015.04.001

Silva, R.C.; Sedor, F.A. \& Fernandes, A.C.S. 2012. Fossil footprints from the Late Permian of Brazil: an example of hidden biodiversity. Journal of South American Earth Sciences, 38:31-43. doi:10.1016/j.jsames.2012.05.001

Simões, M.G.; Matos, S.A.; Anelli, L.E.; Rohn, R.; Warren, L.V. \& David, J.M. 2015. A new Permian bivalve-dominated assemblage in the Rio do Rasto Formation, Paraná Basin, Brazil: faunal turnover driven by regional-scale environmental changes in a vast epeiric sea. Journal of South American Earth Sciences, 64:14-26. doi:10.1016/j.jsames.2015.09.009

Sire, J.Y.; Donoghue, P.C.J. \& Vickaryous, M.K. 2009. Origin and evolution of the integumentary skeleton in non-tretrapod vertebrates. Journal of Anatomy, 214:409-440. doi:10.1111/ j.1469-7580.2009.01046.x

Smith, J.L.B. 1939. A living fish of Mesozoic type. Nature, 143: 455-456. doi:10.1038/143455a0

Toledo, C.E.V. \& Bertini. R.J. 2005. Occurrences of the fossil dipnoiformes in Brazil and its stratigraphic and chronological distribution. Revista Brasileira de Paleontologia, 8:47-56.

Wang, N. \& Liu, H. 1981. Coelacanth fishes from the Marine Permian of Zhejiang, South China. Vertebrata PalAsiatica, 19:305-312.

Weiss, F.E. \& Garcia, S.O. 2005. Sobre a ocorrência de celacanto na Formação Pedra de Fogo, Permiano da Bacia do Parnaíba, no estado do Tocantins, Brasil. Comunicações do Museu de Ciências e Tecnologia da PUCRS. Série Zoologia, 19:39-44.

Yabumoto, Y. \& Neuman, A. 2004. A coelacanth scale from the Upper Triassic Pardonet Formation, British Columbia, Canada. Paleontological Research, 8:337-340. doi:10.2517/prpsj.8.337

Young, G.C. 2008. Relationships of tristichopterids (osteolepiform lobe-finned fishes) from the Middle-Late Devonian of East Gondwana. Alcheringa, 32:321-336. doi:10.1080/03115510802104368

Received in November, 2015; accepted in November, 2016. 